\title{
In vitro Analysis of Morphology of Human Enamel Submitted to Excessive Use of External Bleaching Agents
}

\author{
Análisis in vitro de la Morfología del Esmalte Humano Sometido \\ a un Uso Excesivo de Agentes Blanqueadores Externos
}

Rafael Binato Junqueira; Rodrigo Furtado de Carvalho; Alberto Nogueira da Gama Antunes; Sonia Sotto-Maior Fortes Garcia Rodrigues; Roberto Sotto-Maior Fortes de Oliveira \& Luciana Andrea Salvio

JUNQUEIRA, R. B.; CARVALHO, R. F.; ANTUNES, A. N. G.; RODRÍGUES, S. F. G.; OLIVEIRA, R. S. F. \& SALVIO, L. A. In vitro analysis of morphology of human enamel submitted to excessive use of external bleaching agents. Int. J. Morphol., 29(1):118-122, 2011.

SUMMARY: The aim of this study was to evaluate the effects of external bleaching agents on morphology of human enamel after excessive homemade dental bleaching. 20 intact human third molars were submitted to mesio-distal crosscut and embedded in polystyrene resin. The specimens were submitted to finish and a half of enamel surface of each specimen was covered with cosmetic varnish, meaning control group (G0). The specimens were randomly divided into four groups ( $\mathrm{n}=10)$ : G1 - 1 bleaching session by $16 \%$ carbamide peroxide; G2 - 3 bleaching sessions by $16 \%$ carbamide peroxide; G3 - 1 bleaching session by $22 \%$ carbamide peroxide; G4 -3 bleaching sessions by $22 \%$ carbamide peroxide. Each session lasted 8 hours a day, during two weeks, with 45 days of interval between sessions. In this period, the specimens were kept in artificial saliva at $37^{\circ} \mathrm{C}$. The specimens were observed by scanning electron microscopy and the results showed depression areas, irregularities, erosion, and enamel prisms exposition, which was more evident in G4. It can be concluded that the excess of bleaching produced many alterations on enamel surface, mainly when was used carbamide peroxide in higher concentration.

KEY WORDS: Dental bleaching; Dental enamel; Peroxides.

\section{INTRODUCTION}

The homemade dental bleaching is an aesthetic treatment that has received more acceptance by patients and dentists, and their risks and benefits for dental structures are still discussed (Justino et al., 2004; Attia et al., 2009; Lozada et al., 2000).

The dental market has products with concentrations of 10 to $35 \%$ of carbamide peroxide, and the first are between 10 and $15 \%$. In contact with saliva and oral tissues, carbamide peroxide decomposes in hydrogen peroxide (active agent) and urea. The lower molecular weight of hydrogen peroxide allows it to freely transit by interprismatic spaces, through enamel and dentin, causing oxidation of pigments in these structures. Therefore, compounds with pigmented carbon rings are converted in clearer chains, resulting in dental bleaching effect (Minoux \& Serfaty, 2008; Basting, 2005; Rodrigues et al., 2007; Sulieman, 2000).
Studies have shown that there is a possibility of subclinical changes in superficial micromorphology of the enamel (Basting; Pinto et al., 2004; Miranda et al., 2005; Lopes et al., 2002), although the possibility of reversing these changes is not established yet.

The dental bleaching using carbamide peroxide for long periods also destroys different layers of enamel and produces loss of minerals. Changes may occur on the enamel, dentin e cementum after bleaching. Bleaching agents probably lead to cell destruction of the pulp due to enzymatic inactivation and rupture of normal cellular activity (Portolani \& Candido, 2005).

Society aesthetic appeal leads people to look for whiter teeth. The facility of accessing bleaching agents makes us alert to enlargement of indiscriminate use of these drugs.

Federal University of Juiz de Fora, Brazil. 
JUNQUEIRA, R. B.; CARVALHO, R. F.; ANTUNES, A. N. G.; RODRÍGUES, S. F. G.; OLIVEIRA, R. S. F. \& SALVIO, L. A. In vitro analysis of morphology of human enamel submitted to excessive use of external bleaching agents. Int. J. Morphol., 29(1):118-122, 2011.

The aim of this study was to evaluate, in vitro, the effects of external bleaching agents on human enamel morphology after excessive homemade dental bleaching.

\section{MATERIAL AND METHOD}

Preparation of specimens. The research project of this study was approved by the Ethics Committee in Human Research, of Federal University of Juiz de Fora, MG, Brazil, under report number 113/2008.

Twenty intact human third molars extracted for clinical reasons were cleaned and frozen in saline solution. After defrost at $25^{\circ} \mathrm{C}$, the roots of the teeth were removed and were submitted to mesio-distal crosscut, using both cuts, diamond disk (Labcut 1010 Low Speed Diamond Saw EXTEC, Chicago, USA), in both, under water refrigeration. Vestibular and lingual surfaces were used in this study. These were embedded in polystyrene resin, obtaining 40 specimens. They were submitted to finish, using wet sandpaper with decreasing granulation (400, 600, 800, 1200, 1500 and 2000) under refrigeration until exposing flat enamel areas. A half of the enamel surface in each specimen was covered with cosmetic varnish (Revlon Incorporated, New York, NY, USA), meaning control group (G0). The other half would be later submitted to bleaching agent.

Experimental groups. The specimens were randomly divided into four groups, as shown in Table I. In the period between sessions, the specimens were kept in artificial saliva at $37^{\circ} \mathrm{C}$.

Analysis of Scanning Electron Microscopy. The teeth fragments were removed from polystyrene resin and dehydrated in alcohol and HMDS. Then, they were embedded in stubs and metalized in gold-palladium alloy (MED 010, Balzers Union, Blazers, Linchenstein) to observation in scanning electron microscope (JEOL, JMS 5600 LV, Scanning Electron Microscope, Tokyo, Japan). The enamel surfaces were examined with increased 1000x, 5000x and $10000 \mathrm{x}$.

\section{RESULTS}

The photomicrography representing superficial morphology of non-bleached (G0) and bleached parts of each group is shown in Figures 1 to 8.

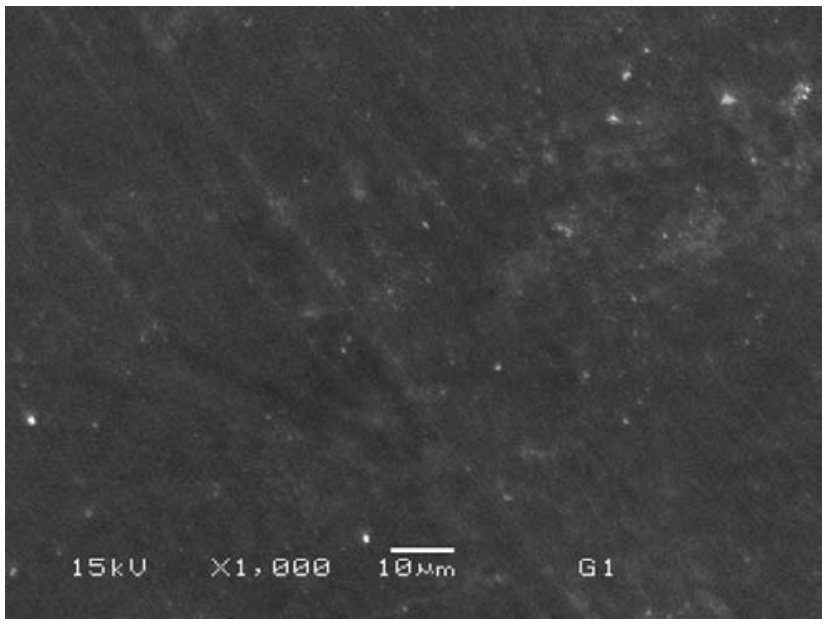

Fig. 1. SEM image of a non-bleached enamel region of a G1 specimen.

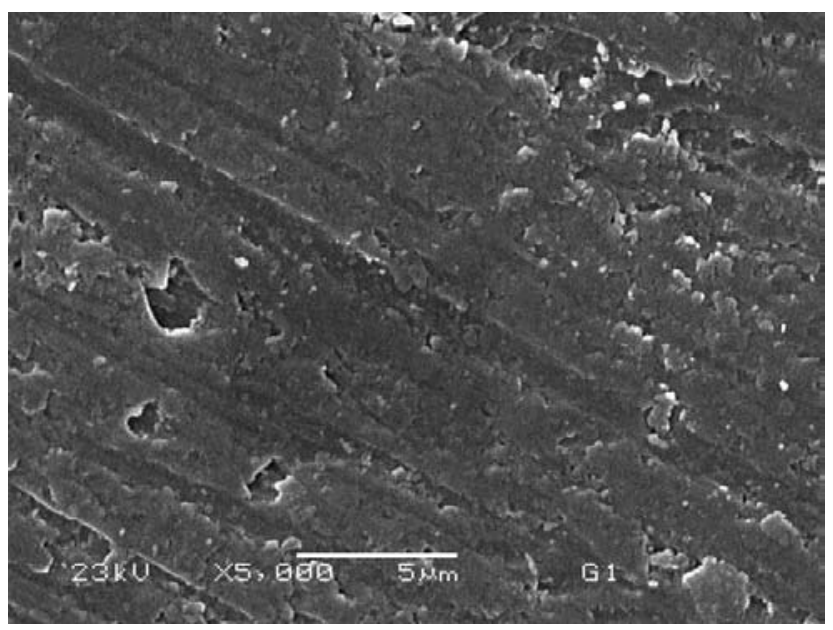

Fig. 2. SEM image of a bleached enamel region of a G1 specimen, showing irregularities and depression areas.

Table I. Experimental groups with respectives used bleaching agents, number, duration and interval between sessions.

\begin{tabular}{lcccc}
\hline Group $(\mathbf{n}=10)$ & Bleaching Agent & n sessions & Duration of each session & Interval between sessions \\
\hline G1 & Carbamide Peroxide 16\%* & 1 & 8h/day for 14 days & - \\
G2 & Carbamide Peroxide 16\%* & 3 & $8 \mathrm{~h} /$ day for 14 days & 45 days \\
G3 & Carbamide Peroxide 22\%* & 1 & 8h/day for 14 days & - \\
G4 & Carbamide Peroxide 22\%* & 3 & 8h/day for 14 days & 45 days \\
\hline
\end{tabular}

*Whiteness Perfect®-FGM Dental Products, Joinvile, SC, Brazil. 


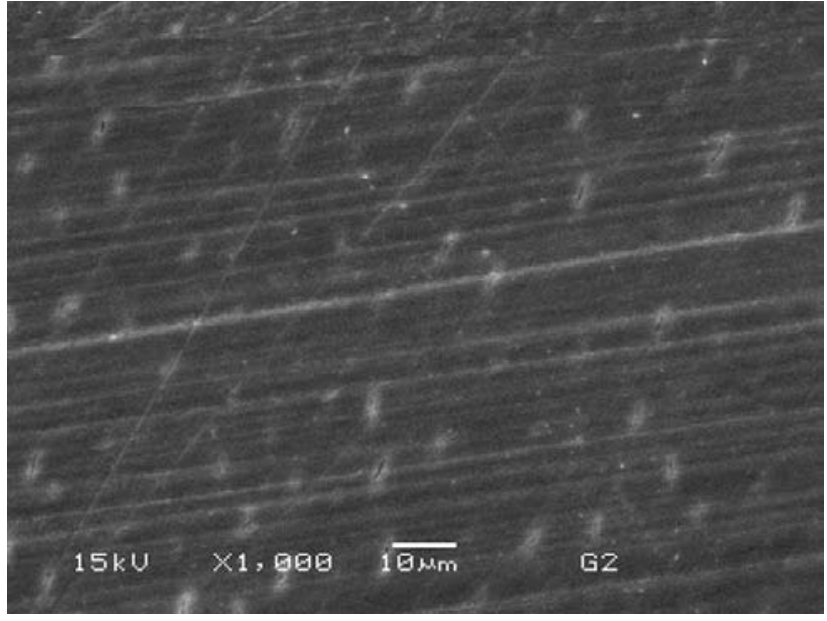

Fig. 3. SEM image of a non-bleached enamel region of a G2 specimen.

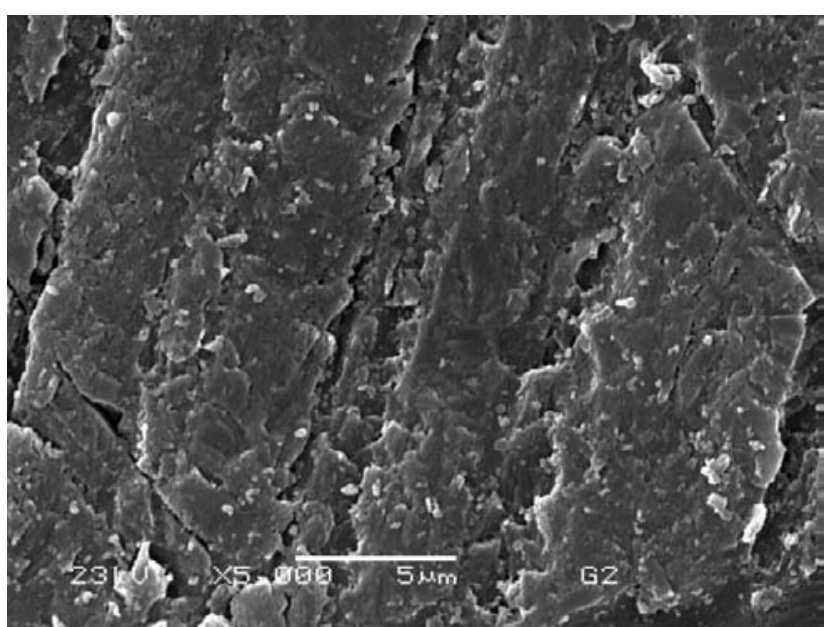

Fig. 4. SEM image of a bleached enamel region of a $\mathrm{G} 2$ specimen, showing irregularities and depression areas.

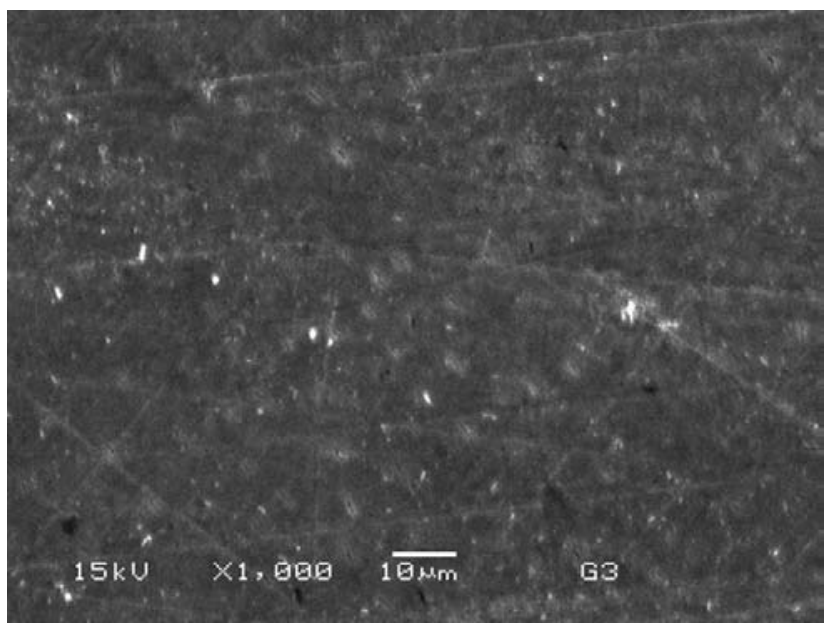

Fig. 5. SEM image of a non-bleached enamel region of a G3 specimen.

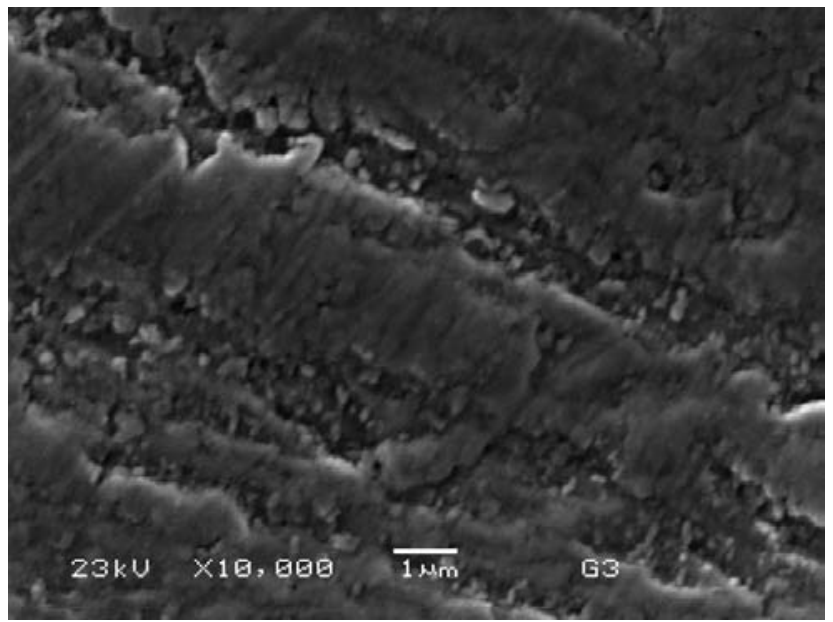

Fig. 6. SEM image of a bleached enamel region of a G3 specimen, showing irregularities and depression areas.

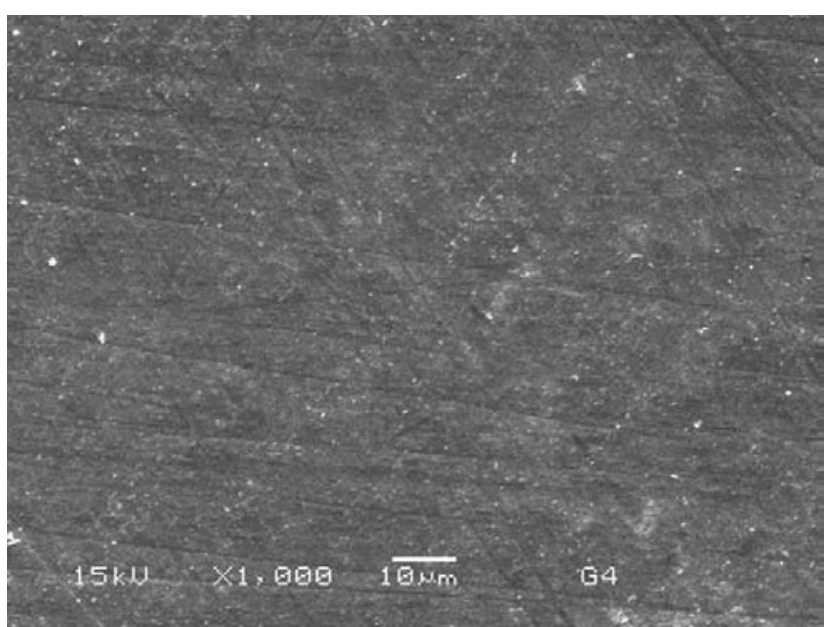

Fig. 7. SEM image of a non-bleached enamel region of a G4 specimen.

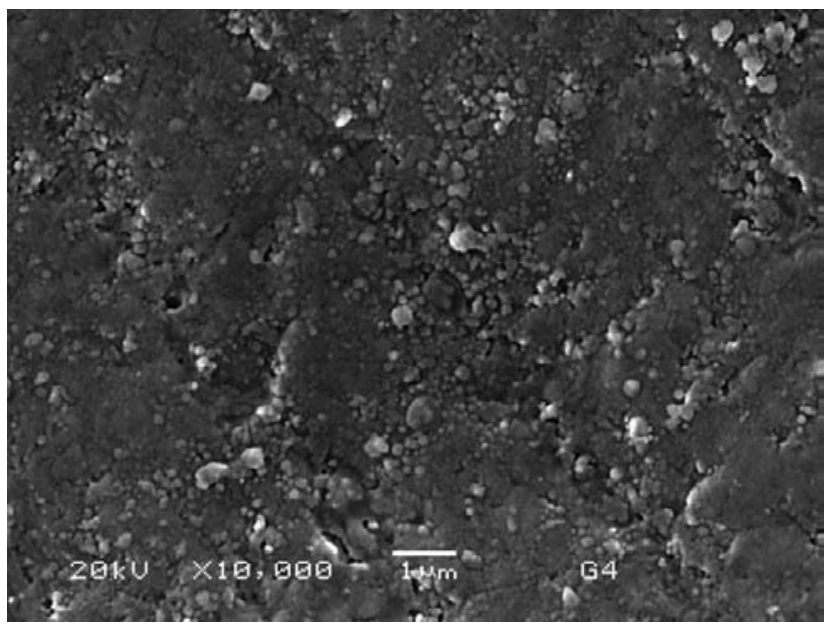

Fig. 8. SEM image of a bleached enamel region of a G4 specimen, showing exposition of enamel prisms and increase of the irregularities depth and pores. 
There were no significant morphological alterations on non-bleached enamel surfaces in different groups. Moreover, bleached surfaces showed some significant changes. Irregularities and depression areas were more evident in groups 1, 2 and 3. Specimens treated with 22\% carbamide peroxide by three sessions (G4) presented enamel prisms exposition, depressions, erosion, increase of the irregularities depth and pores.

\section{DISCUSSION}

The results of this study indicated that carbamide peroxide, in 16 or $22 \%$ concentration, caused alterations on human enamel morphology. In accordance, some studies have been showing changes on enamel superficial morphology, as loss of hydroxyapatite crystals (Basting; Pinto et al.; Miranda et al.; Lopes et al.) after homemade dental bleaching using carbamide peroxide.

Some studies found no alterations in the enamel bleached with carbamide peroxide at low concentrations (10\%), concluding that there is no risk when using it for two to five weeks in homemade dental bleaching (Dudea et al., 2009; Çobankara et al., 2004; Meireles et al., 2008; Pugh et al., 2005; Peña \& Cabrita, 2006; Caballero et al.,
2006). However, there are no tests using the same peroxide at $22 \%$ concentration for six weeks, as shown in this study.

Changes on surface morphology were more evident in specimens bleached with carbamide peroxide $22 \%$ for three sessions (G4). In figure 8 we could observe the loss of aprismatic layer, depressions, erosion, increase of the irregularities depth and pores, when compared to other groups. Such changes may be related to a significant reduction in microhardness in these specimens excessively bleached, as reported by Pinto et al.

Another fact to be considered is the influence of storage solution. According to some authors, the artificial saliva, where specimens are kept in the period between applications of the bleaching agent, lead to the remineralization of the bleached enamel surface (Miranda et al.; Maia et al., 2008). This fact was not observed in this study, since there were morphological changes compared with the non-bleached enamel.

In light of the facts presented it was concluded that the excess of bleaching, both in time and concentration, had a negative influence on the morphology of enamel. As a clinical implication it is worth noting that the home dental bleaching should be done with caution, since changes are evident.

JUNQUEIRA, R. B.; CARVALHO, R. F.; ANTUNES, A. N. G.; RODRÍGUES, S. F. G.; OLIVEIRA, R. S. F. \& SALVIO, L. A. Análisis in vitro de la morfología del esmalte humano sometido a un uso excesivo de agentes blanqueadores externos. Int. J. Morphol., 29(1):118-122, 2011.

RESUMEN: El objetivo de este estudio fue evaluar los efectos en la morfología externa del esmalte humano al utilizar excesivamente agentes blanqueadores dentales de uso casero. Se cortaron 20 intactos terceros molares humanos en sentido mesiodistal, luego fueron sumergidas las porciones radiculares en resina de poliestireno. Las muestras fueron pulidas, cubriendo la mitad de la superficie del esmalte con barniz cosmético, representando así al grupo control (G0). Las muestras fueron distribuidas aleatoriamente en cuatro grupos ( $\mathrm{n}=10)$ : G1-Una sesión de blanqueamiento con peróxido de carbamida al 16\%, G2. Tres sesiones de blanqueamiento con peróxido de carbamida al 16\%, G3-Una sesión de blanqueamiento con peróxido de carbamida al 22\%, G4- Tres sesiones de blanqueamiento con peróxido de carbamida al 22\%. Cada sesión tuvo una duración de 8 horas diarias durante dos semanas con 45 días de intervalo entre sesiones. Durante ese periodo las muestras fueron mantenidas en saliva artificial a $37^{\circ} \mathrm{C}$. Las muestras fueron observadas al microscopio electrónico de barrido, mostrando aéreas de depresión, irregularidades, erosiones y exposición de prismas del esmalte. Esto fue más evidente en G4. Se puede concluir que el exceso de blanqueamiento producido muchas alteraciones en la superficie del esmalte, sobre todo cuando se utilizó peróxido de carbamida en alta concentración.

PALABRAS CLAVE: Blanqueamiento dental; Esmalte dental; Peróxidos.

\section{REFERENCES}

Attia, M. L.; Aguiar, F. H. A.; Mathias, P.; Ambrosano, G. M. B.; Fontes, C. M. \& Liporoni, P. C. S. The effect of coffee solution on tooth color during home bleaching applications. Am. J. Dent., 22:175-9, 2009.
Basting, R. T. Peróxido de carbamida: efeitos na micromorfologia e rugosidade das estruturas dentais. Arq. Odontol., 41:21-7, 2005. 
JUNQUEIRA, R. B.; CARVALHO, R. F.; ANTUNES, A. N. G.; RODRÍGUES, S. F. G.; OLIVEIRA, R. S. F. \& SALVIO, L. A. In vitro analysis of morphology of human enamel submitted to excessive use of external bleaching agents. Int. J. Morphol., 29(1):118-122, 2011.

Caballero, A. B.; Navarro, L. F. \& Lorenzo, J. A. At-home vital bleaching: comparison of hydrogen peroxide and carbamide peroxide treatments. Med. Oral Pathol. Oral Cir. Bucal, 11:E94-9, 2006.

Çobankara, F. K.; Ünlü, N.; Altinöz, H. C. \& Özer, F. Effect of home bleaching agents on the roughness and surface morphology of human enamel and dentine. Int. Dent. J., 54:211-8, 2004.

Dudea, D.; Florea, A.; Mihu, C.; Câmpeanu, R.; Nicola, C. \& Benga, G. H. The use of electron microscopy in evaluating the effect of a bleaching agent on the enamel surface. Rom. J. Morphol., Embryol., 50:435-40, 2009.

Justino, L. M.; Tames, D. R. \& Demarco, F. F. In situ and in vitro effects of bleaching with carbamide peroxide on human enamel. Oper Dent., 29:219-25, 2004.

Lopes, G. C.; Bonissoni, L.; Baratieri, L. N.; Vieira, L. C. \& Monteiro, Jr. S. Effect of bleaching agents on the hardness and morphology of enamel. J. Esthet. Restor. Dent., 14:24-30, 2002.

Lozada, O.; García, C. \& Alfonso, I. Riesgos y benefícios del blanqueamiento dental. Acta Odontol. Venez., 38:417, 2000 .

Maia, E.; Baratieri, L. N.; Andrada, M. A. C.; Monteiro, Jr. S. \& Vieira, L. C. C. The influence of two home-applied bleaching agents on enamel microhardness: an in situ study. J. Dent., 36:2-7, 2008.

Meireles, S. S.; Heckmann, S. S.; Leida, F. L.; Snatos, I. S.; Della Bona, A. \& Demarco, F. F. Efficacy and safety of $10 \%$ and $16 \%$ carbamide peroxide tooth-whitening gels: a randomized clinical trial. Oper. Dent., 33:606-12, 2008.

Minoux, M. \& Serfaty, R. Vital tooth bleaching: biologic adverse effects - a review. Quintessence Int., 39:64559, 2008.

Miranda, C. B.; Pagani, C.; Benetti, A. R. \& Matuda, F. S. Evaluation of the bleached human enamel by scanning electron microscopy. J. Appl. Oral Sci., 13:204-11, 2005.

Peña, V. A. \& Cabrita, B. Comparison of the clinical efficacy and safety of carbamide peroxide and hydrogen peroxide in at-home bleaching gels. Quintessence Int., 37:551-6, 2006.

Pinto, C. F.; Oliveira, R.; Cavalli, V. \& Giannini, M. Peroxide bleaching agent effects on enamel surface microhardness, roughness and morphology. Braz. Oral Res., 18:306-11, 2004.

Portolani, Jr. M. V. \& Candido, M. S. M. Efeito dos agentes clareadores sobre as estruturas dentais. Rev. Odontol. UNESP, 34:91-4, 2005.

Pugh, Jr. G.; Zaidel, L.; Lin, N.; Stranick, M. \& Bagley, D. High levels of hydrogen peroxide in overnight toothwhitening formulas: effects on enamel and pulp. $J$. Esthet. Restor. Dent., 17:40-7, 2005.

Rodrigues, J. A.; Oliveira, G. P. F. \& Amaral, C. M. Effect of thickener agents on dental enamel microhardness submitted to at-home bleaching. Braz. Oral Res., 21:1705, 2007.

Sulieman, M. A. M. An overview of tooth-bleaching techniques: chemistry, safety and efficacy. Periodontol. 2000, 48:148-69, 2008.

Correspondence to:

Rafael Binato Junqueira

Universidade Federal de Juiz de Fora

Faculdade de Odontologia

Campus Universitário, s/n

Martelos 36036-900

Juiz de Fora

$M G$ - BRAZIL

Received: 17-08-2010

Accepted: 21-11-2010 